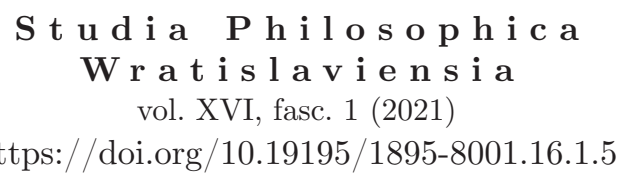

ZBIGNIEW PIETRZAK

ORCID: 0000-0003-2458-1252

Uniwersytet Wrocławski

\title{
Czy zwierzę może być dziełem sztuki. Kilka refleksji na marginesie książki Jerzego Lutego Sztuka jako adaptacja
}

\author{
Can an animal be a work of Art: \\ A few reflections inspired by the book Sztuka jako adaptacja \\ [Art as Adaptation] by Jerzy Luty
}

\begin{abstract}
Art as Adaptation [published in Polish as Sztuka jako adaptacja], a book by Jerzy Luty, provokes one to seek the roots of art not only in cultural processes but also in biological (evolutionary) processes. The consequences of this evolutionistic perspective render the question whether other species, apart from human beings, create art, and if so, how it manifests itself valid. In this paper, I emphasise that if we recognise art as the effect of evolutionary processes, we should also face the fact that at least some species of animals should be treated as authors or creators to some degree. What is more, we should recognise that these animals themselves are works of art. To justify this thesis, naturalists point to birds.

The recognition that animals can create art implies another question, namely, whether they have an aesthetic sense. Finally, there is one more question that needs to be reflected upon, which is whether nature itself is beautiful (ugly), or aesthetically neutral, analogous to the question of whether it is good or bad. The latter question is ontological.
\end{abstract}

Keywords: evolution, sexual selection, adaptationism, work of art 


\section{Wstęp}

Teoria ewolucji należy do tych naukowych idei, które nie tylko zrewolucjonizowały nasze myślenie o przyrodzie i miejscu człowieka w naturze, ale także ze względu na swoja uniwersalność wyznaczały nowe ramy interpretacji zjawisk zachodzących w otaczającym nas świecie. Umożliwiały one wyjaśnienie niezrozumiałych dotąd faktów oraz prognozowanie dotychczas nieobserwowanych zdarzeń. Taki status teorii rodzi jednak pokusę, by tylko w ich ramach poszukiwać odpowiedzi na pytania o mechanizmy, źródła, funkcje, a nawet cele obserwowanych i badanych zjawisk. Mówiąc inaczej, oczekuje się, by „wszystko" wyjaśniały.

Teoria ewolucji, ponieważ dotyczy zdarzeń zachodzących w przyrodzie ożywionej, jest szczególnie podatna na tego rodzaju metodologiczne „nadużycia”. Wynika to między innymi ze złożoności zjawisk biologicznych, które mogą, czy nawet powinny być wyjaśniane i opisywane w perspektywie wykraczającej poza fizykę i chemię. Ramy te można nakreślić dzięki odpowiednio zdiagnozowanym przyczynom obserwowanych zjawisk i właściwie sformułowanym pytaniom dotyczącym owych przyczyn. Jerzy Luty zwraca uwagę ${ }^{1}$, że współczesna biologia dysponuje takim „katalogiem” przyczyn i pytań, którego twórcą jest Nikolaas Tinbergen². Zaproponowany przez tego biologa kompleks przyczyn i pytań znany jest w historii biologii jako „cztery przyczyny Tinbergena” lub „cztery pytania Tinbergena”.

Owe pytania można przedstawić, na przykład, w wersji podanej przez Krebsa i Davisa:

— „W kategoriach wartości lub funkcji dla przeżycia”; wiążą się one z pytaniem o przyczyny „ultymatywne”, „ostateczne”;

— „w kategoriach przyczynowości lub mechanizmu [...] dotyczą one czynników zewnętrznych i wewnętrznych”; wiążą się z pytaniem o przyczyny „bezpośrednie”;

— „w kategoriach rozwoju" wiążą się z pytaniem o przyczyny rozwojowe, w kontekście ontogenezy;

— „w kategoriach historii ewolucyjnej” wiążą się z pytaniem o przyczyny ewolucyjne, a więc w kontekście filogenezy ${ }^{3}$.

1 J. Luty, Sztuka jako adaptacja. Uniwersalizm w estetyce ewolucyjnej, Kraków 2018, s. 39.

2 Nikolaas Tinbergen (1907-1988). Autor znanej książki Badania nad instynktem, tłum. G. Bujalska-Grüm, L. Grüm, Warszawa 1976, Choć książka ta już nieco się zdezaktualizowała (pojęcie instynktu zostało praktycznie wyrugowane z etologii), to nadal stanowi przykład doskonałej literatury popularnonaukowej, opisującej między innymi warsztat pracy przyrodnika.

3 J.R. Krebs, N.B. Davies, Wprowadzenie do ekologii behawioralnej, tłum. M. Golachowski, Warszawa 2014, s. 5-6 (kursywa w oryginale). Autorzy powołują się na pracę Tinbergena, z 1963 roku, On aims and methods of ethology, „Zeitshrift für Tierpsychologie” 20, s. 410-433. Ernst Mayr powyższe pytania ujmuje w dwa typy: pytania o przyczyny „bezpośrednie” i „ultymatywne”. Te pierwsze nazywa także przyczynami funkcjonalnymi (na przykład procesy fizjologiczne, chemiczne itp.) i wiąże je z pytaniem ,jak" — ,,jak funkcjonuja procesy chemiczne”. Te drugie określa również mianem przyczyn pośrednich, ultymatywnych lub ewolucyjnych (przyczyny takie prowadzą do powstania nowego typu jakości, programów itp.). Ten typ przyczyn wiąże z pytaniem „dlaczego?”. W kontekście tego pytania — jak podkreśla to Mayr — metody fizyki i chemii częściowo zawodzą, a biologia może odwoływać się do obu przyczyn, wyjaśniając to samo zjawisko; por. E. Mayr, To jest biologia. Nauka o świecie ożywionym, tłum. J. Szacki, Warszawa 2002, s. 63. 
Odwołując się do nich, Krebs uzmysławia czytelnikowi, że są one różnie sformułowanymi wersjami pytania „dlaczego?”; że można stawiać je na cztery sposoby i na cztery sposoby odpowiadać na nie, wskazując na przyczyny takiego, a nie innego wyglądu, funkcji organów, a także zachowań zwierząt. Jest to o tyle istotne, że właśnie owo pytanie „dlaczego?” jest zasadne w naukach biologicznych, ale już nie w fizyce czy chemii. Tinbergen, formułując powyższe pytania i kategoryzując przyczyny leżące u podstaw zjawisk przyrodniczych, podkreśla owo przekonanie, że procesów biologicznych nie można redukować do reakcji chemicznych, czy nawet do najbardziej fundamentalnych zasad fizycznych. Przyjęcie takiego założenia pozwala biologom na poszukiwanie przyczyn wyrażonych w pytaniu „dlaczego?", które to pytanie w fizyce lub chemii wydaje się nonsensowne lub co najmniej niewłaściwie postawione. Nie pytamy przecież „dlaczego istnieje Wszechświat” lub „dlaczego sa lawiny?"4, tak jak nie pytamy o kwestie etyczne w odniesieniu i do Kosmosu, i do lawin. Tymczasem pytania „dlaczego zwierzę zachowuje się tak, a nie inaczej?", „dlaczego ma taki, a nie inny wygląd?", ,,jaki jest cel takich, a nie innych relacji wewnątrz populacji?" itp. są już całkowicie uzasadnione. W każdym przypadku, nie popełniając jakichś metodologicznych błędów, możemy na nie odpowiedzieć, wskazując adekwatne przyczyny.

Różne sposoby rozumienia tego pytania, a tym samym i sposoby udzielanych na nie odpowiedzi, które wskazują przyczyny badanych zjawisk, uzmysławiają złożoność przyrody ożywionej. Pytając bowiem o jakieś jedno konkretne zjawisko, możemy formułować wiele różnych odpowiedzi, w których odwołujemy się do różnych przyczyn. Co więcej, wszystkie te odpowiedzi mogą być poprawne. Natomiast jedna odpowiedź, choć prawdziwa, może okazać się niewystarczająca i ograniczająca nasze poznanie. Można pokusić się o stwierdzenie, że w biologii brzytwa Ockhama ma częściej negatywne niż pozytywne skutki.

W konsekwencji zadanie pytania „dlaczego?” w odniesieniu do zjawisk obserwowanych w świecie przyrody ożywionej sprawia, że możemy zasadnie stawiać je także w kontekście zjawisk behawioralnych i kulturowych. A tym samym poszukiwać ich przyczyn, które wykraczajac poza „przyczyny bezpośrednie” (,funkcjonalne”). Formułujac tylko pytanie „jak?" w odniesieniu do sfery, która nie jest czysto fizykalna, popełnilibyśmy metodologiczny, filozoficzny, a pewnie też i ontologiczny „grzech” redukcjonizmu. Pytanie „jak działa kultura?” nie wyjaśnia wielu zjawisk związanych z tą sferą, a przede wszystkim nie dotyczy jej genezy i celu. Ten kontekst obejmuje oczywiście także sztukę, będącą egzemplifikacją kultury.

\section{Pytanie o sztukę}

Czy analizując fenomen sztuki i przyjmując nawet, że jest ona wytworem tylko człowieka, kategorie pytań i przyczynowości Tinbergena moga poszerzyć zakres poszukiwanych odpowiedzi dotyczących tej dziedziny? Czy mogą ujawnić nowe

${ }^{4}$ Oczywiście w języku i myśleniu potocznym możemy to pytanie sformułować w ten sposób, uznając w domyśle, że za pytaniem „dlaczego" kryje się sens wyrażony w pytaniu „jakie są mechanizmy” powstania i działania „czegos”. Nie zajmujemy się tu jednak codzienną praktyką językową. 
problemy? Sądzę, że tak, że w perspektywie owych czterech pytań pojawiają się interesujące problemy i nowe możliwości ich interpretacji.

W niniejszych rozważaniach chciałbym pokrótce poruszyć tę kwestię, tym bardziej, że — jak już o tym wspomniałem — Jerzy Luty przywołuje owe pytania w kontekście etologii.

Wyjaśnianie powstania i trwania fenomenu sztuki jako adaptacji sprawia, że jesteśmy zmuszeni do poszukiwania jakichś jej analogii, artefaktów poza naszym gatunkiem. Inaczej bowiem przyznajemy rację poglądowi, że między naszym gatunkiem a pozostałymi organizmami istnieje ontologiczna „przepaść”. Taka „nieciągłość" burzyłaby zasadnicze przesłanie treści teorii ewolucji (i być może także jej heurystyczną spójność), głoszącej gradualizm w sferze somatycznej i behawioralnej ${ }^{5}$. Rozumiejąc adaptację ,,jako zmiany, jakie w procesie ewolucji przyniósł dobór naturalny" ${ }^{\prime \prime}$, n niniejszych rozważaniach odniosę się przede wszystkim do konsekwencji, które wynikają z postawienia czwartego pytania dotyczącego kategorii „historii ewolucyjnej”, a więc wiążącego się z pytaniem o przyczyny ewolucyjne.

Oczywiste staje się zatem pytanie, czy znamy zwierzęta, które tworzyłyby coś, co można byłoby nazwać sztuką. Luty poświęca temu zagadnieniu rozdział szósty zatytułowany „Czy istnieje sztuka zwierząt albo o ewolucyjnej ciągłości gatunków". Diagnozując ewentualną twórczość zwierząt i tym samym obecność sztuki w świecie pozaludzkim, musimy kierować się jakąś definicją tego, czym jest sztuka. Jak uzmysławia nam autor, na przykład zastosowanie „ekspresjonistycznej definicji sztuki" pozwala, a przynajmniej ułatwia, zaklasyfikowanie obrazów namalowanych przez szympansa Congo jako sztuki ${ }^{7}$. Jednakże pojawia się inny problem. Otóż jeżeli za sztukę uznamy te wytwory, które skupiają naszą uwage po zakończeniu pracy, to pojawia się pytanie, czy Congo lub inne szympansy „podziwiały” je, a nawet oceniały („kryterium krytyki”). Sądzę, że kierowanie się wymienionymi definicjami sztuki i w konsekwencji zawężony (według mnie) sposób jej rozumienia, uniemożliwia rozstrzygnięcie tej kwestii. Tak rozumianą sztukę wiążemy bowiem z czysto ludzką perspektywą skupiającą się na jakiejś formie aktywności (działalności), przejawiającej się choćby w manualnym operowaniu przedmiotami (obrazy, rzeźby, architektura), dźwiękiem (wokalizacja), czy też językiem, pojęciami (mity, literatura, a może nawet i matematyka). Już sam zapis dźwięków, na przykład kaligrafia, jest przecież traktowany jak sztuka. Uznanie za przejaw sztuki efektów działania innych gatunków, wiązać się będzie z akceptacją myśli, że owe „działania” są jakąś formą (wy)twórczości ${ }^{8}$. Tak rozumiana sztuka dotyczyłaby wytworów, które stanowią - pozwolę sobie na takie sformułowanie — twórczość pozasoma-

${ }^{5}$ Na przykład zwolennikiem gradualizmu w sferze świadomości jest prymatolog Frans de Waal; por. F. de Waal, Bystre zwierzę. Czy jesteśmy dość mądrzy, aby zrozumieć mądrość zwierząt, tłum. Ł. Lamża, Kraków 2016, s. 284.

6 J.R. Krebs, N.B. Davies, Wprowadzenie do ekologii behawioralnej, s. 9; por. także J. Luty, Sztuka jako adaptacja, s. 18-19. O adaptacji możemy mówić nawet w odniesieniu do ontogenezy. W tym przypadku, należałoby ją rozumieć jako przystosowanie się (lub wychowanie) do życia w określonym społeczeństwie i kulturze.

7 J. Luty, Sztuka jako adaptacja, s. 165, 170 n.

8 Por. ibidem, s. 134 n. 
tyczną ${ }^{9}$. A to, podkreślę raz jeszcze, uniemożliwia spojrzenie na efekty działań zwierząt jak na dzieła sztuki, nawet gdy chodzi o gniazda wikłaczy czy areny tokowe altanników ${ }^{10}$.

Rozumienie sztuki jako tylko efektu „wytwórczości” ujawnia swoje ograniczenia, gdy uzmysłowimy sobie, że może przejawiać się ona w zaskakująco odmienny sposób - to sam organizm może być dziełem sztuki. Sztuki, ponieważ jest efektem estetycznej wrażliwości i potrzeby estetycznych doznań twórcy, którym w tym wypadku jest partner seksualny. Tego rodzaju ideę nasuwa lektura książki Richarda O. Pruma Ewolucja piękna ${ }^{11}$. Autor wskazuje, że zrozumienie różnorodności ptasiej ornamentyki nie będzie możliwe, jeśli nie uwzględni się teorii doboru płciowego. Co więcej, w świetle tej teorii okazuje się, że adaptacjonizm nie ma wystarczającej mocy eksplanacyjnej. Prum pisze:

podobnie jak oczy [...] i pióra, mechaniczne odgłosy wydawane przez gorzyki są przykładami ewolucyjnych innowacji — całkowicie nowych biologicznych cech, które nie są homologiczne z jakąkolwiek cechą przodków [...]. Ewolucyjne innowacje [...] wymagają czegoś więcej niż tylko powolnej stopniowej, ilościowej zmiany. [...] W ostatnich latach biolodzy odkryli, że adaptacja zapewnia w najlepszym razie niepełny obraz procesu ewolucyjnej innowacji. Mam nadzieję, że poprzez przedstawienie tu mechanizmu innowacji estetycznej, będziemy mogli zobaczyć, że adaptacyjny wybór partnera nie zapewni również dostatecznego wyjaśnienia pochodzenia i zróżnicowania ornamentów ${ }^{12}$.

Innymi słowy, jeśli chcielibyśmy mówić o sztuce jako adaptacji, to odwołując się do doboru naturalnego, należy także uwzględnić dobór płciowy (estetyczny). Przewodnią myślą książki Pruma jest idea głosząca, że pewne zachowania i wygląd tracą swoją pierwotną funkcję pod wpływem estetycznej wrażliwości partnera seksualnego. Na przykład „poprzez estetyczną koewolucję, te przypadkowe dźwięki (mechaniczne odgłosy wydawane przez gorzyki) stały się obiektem [estetycznej — Z.P.] preferencji samic"13. Dotyczy to jak najbardziej innych aspektów całej palety ptasich (zwierzęcych) zachowań godowych.

Prum jest ornitologiem i dlatego też, wskazując na rolę doboru płciowego w kształtowaniu różnorodnych form seksualnej (godowej) aktywności, sięga po przykłady ze świata ptaków. Nie będzie jednak przesady w stwierdzeniu, że opisywane przez Pruma zachowania i stroje godowe, śpiewy, a nawet architektoniczna twórczość mogą być odnajdywane w zwyczajach innych zwierząt. Trudno nam jednak zaakceptować, że ornamentyka motyli jest efektem tych samych mechanizmów co ornamentyka ptaków lub gadów (na przykład układ kolorystyczny skóry węży). Stoi za tym przekonanie, iż wrażliwość estetyczna wiąże się z jakąś formą ,świadomości", którą jesteśmy skłonni przypisać ptakom, być może i gadom, lecz owadom już nie. W tym kontekście celowo nie wspominam o ssakach.

${ }^{9} \mathrm{~W}$ pewnym sensie przypomina to ideę fenotypu rozszerzonego zaproponowana przez Richarda Dawkinsa; por. R. Dawkins, Fenotyp rozszerzony. Dalekosiężny gen, tłum. J. Gliwicz, Warszawa 2003.

10 J. Luty, Sztuka jako adaptacja, s. 172.

11 R.O. Prum, Ewolucja piękna. Jak Darwinowska teoria wyboru partnera kształtuje świat zwierząt i nas samych, tłum. K. Skonieczny, Kraków 2019.

12 Ibidem, s. 138.

13 Ibidem, s. 139; por. także s. 138-139. 
W konsekwencji jednak musimy uznać, że wygląd zwierzęcia (a także człowieka) jest jakąś formą sztuki, czy też przejawem artystycznego spojrzenia ${ }^{14}$.

W tym kontekście należy zauważyć, co moim zdaniem Luty czyni w niewystarczającym stopniu, że wspominane „kryterium krytyki” służące do uznania czegoś za sztukę jest spełniane tak powszechnie, iż nie może być uznane za incydentalne i przypadkowe ${ }^{15}$. Otóż wspomniane już tańce gorzyków, gniazda wikłaczy czy altanki altanników są oceniane (podziwiane?) przez samice. Stają się zatem, w dosłownym rozumieniu, przedstawieniami czy też galeriami z wystawionymi na pokaz dziełami twórczej pracy. Czyż zatem nie jest to sztuka? Samice dokonujące wyborów stają się przy tym niejako kreatorami sztuki w tym sensie, w jakim odbiorca może kreować nowe trendy, a więc wpływać na ewolucję, jakość i nowatorstwo efektu pracy artysty. Pogląd ten wzmacnia zachowanie ocenianych zwierząt. Zarówno biorące udział w tańcach gorzyki, jak i prezentujące swoje gniazda wikłacze lub altanki altanniki, ćwiczą przez lata swoje umiejętności, a negatywnie oceniony układ czy konstrukcja są zmieniane. Gniazda są po prostu rozbierane i budowane od nowa. Jednakże taka ocena opisanych przykładów staje się heurystycznie i eksplanacyjnie zasadna dopiero w świetle idei głoszonych przez Pruma. Dopiero wówczas także i myśl, że ciało zwierzęcia, a ściślej jego ornamentyka i takie wytwory jak rogi, poroże, ciosy itp. mogą być potraktowane jako efekt twórczej, estetycznej wrażliwości, wydaje się już mniej kontrowersyjna, a tym bardziej mniej niedorzeczna. Najsłynniejszym przykładem tak rozumianego dzieła sztuki jest „ogon pawia”"16 czy opisywany przez Pruma i wspominany przez Lutego ogon argusa malajskiego. Takie przykłady można byłoby mnożyć. Nawet wśród ptaków występujących w Polsce jest wiele gatunków, w których samce zdecydowanie są barwniejsze, mają bardziej kolorową, ozdobną ornamentykę niż samice. Możemy podać przykład licznych gatunków kaczek (ale już nie gęsi), kuraków, bataliona, ptaków śpiewających itp. Niekiedy różnice są bardzo subtelne i ograniczają się do mało uchwytnych „detali” takich, jak układ piór, kolor dzioba, bardziej błyszczące pióra itp.

Znamienne, że o owym estetycznym wyborze wspominał już Darwin, przytaczając relacje przyrodników opisujących pokazy godowe, między innymi, ptaków rajskich (obecnie nazywanych cudowronkami): ,samice przypatrują się temu i wybieraja najbardziej ponętnego partnera. Kto z bliska obserwował ptaki w niewoli, ten dobrze wie, że mają one swoje osobiste sympatie i antypatie"17.

Można byłoby pokusić się o stwierdzenie, że są to dzieła sztuki, lecz inaczej kreowane i realizowane za pomocą innych środków niż w przypadku gniazd, aren tokowych, a nawet śpiewu czy tańca. Tu twórca i tworzywo to jedność. Odchodzi się tu od rozumienia sztuki jako fizycznego działania, jako techne. Dlatego jest ono tak

14 Być może najbardziej jaskrawym tego przykładem jest kulturystyka. W tym sporcie ciało jest tworzywem, jest — jak twierdzą kulturyści — rzeźbione, a i efekt estetyczny nie jest tu bez znaczenia. Pokazy kulturystyczne przypominają pokazy mody czy konkursy „miss”.

15 Por. J. Luty, Sztuka jako adaptacja, s. 172 n.

16 Warto przy tym zauważyć, że owe ozdobne pióra, czyli „ogon”, nie są piórami ogonowymi (sterówkami). Są to pióra wyrastające na plecach.

17 C. Darwin, O powstawaniu gatunków, tłum. S. Dickstein, J. Nusbaum (oprac. J. Popiołek, M. Yamazaki), Warszawa 2013, s. 85; por. także T. Hanson, Pióra. Ewolucja cudu natury, tłum. A. Wawrzyński, Łódź 2019, s. 211-225. 
różne od tego, co robi człowiek, a tym samym dalekie od jego sposobu pojmowania sztuki, gdzie tworzywo i twórca są odmienne. Gdyby poszukiwać jakiejś analogii do tak pojmowanej sztuki, w której ciało zwierzęcia jest tworzywem oraz do sposobów jej realizacji, to przywołałbym współczesny nurt nazywany bio-artem. Luty, powołując się na Pruma i wykorzystując podane przez niego przykłady i argumenty, nie formułuje jednak tezy, że zwierzę jest dziełem sztuki, a partner artystą ${ }^{18}$. Osobiście uważam, że zwierzę jest i dziełem sztuki, i artystą. Do zajęcia takiego stanowiska przekonują mnie słowa wybitnego ornitologa Goeffreya E. Hilla: „Kiedy spytamy ornitologa dlaczego ptaki są tak pięknie ubarwione, usłyszymy prostą odpowiedź, że musi tak być »ponieważ wyboru partnera dokonują samice«. [...] [T]ylko odwołując się do wyboru partnera przez samice, sprawiamy, że satysfakcjonujące staje się wyjaśnienie wspaniałych i ekstrawaganckich kolorów" wielu gatunków ptaków ${ }^{19}$.

W kontekście przyczyn ewolucyjnych (historii ewolucyjnej) należy zapytać także, w jakim stopniu ową wyszukaną ornamentykę, zachowania godowe i śpiewy możemy uznać za sztukę, a w jakim za efekty mimetyzmu lub mimikry. W jakim stopniu jest to przykład preferencji estetycznych, a nie sztuki kamuflażu jednoznacznie wzmacnianego przez dobór naturalny. Zwierzę mniej widoczne dla drapieżnika ma większą szansę na przeżycie. Egzystencja zwierząt (także i roślin, a do pewnego czasu również i człowieka) jest wypadkową ich zdolności do ukrywania się i korzystnego w kwestii przetrwania naśladownictwa oraz konieczności manifestacji swojej obecności. Tkwi w tym oczywista i determinująca przeżycie sprzeczność — potrzeba kamuflowania się i ,autoprezentacji”. Manifestacja obecności, szczególnie widoczna w okresie godowym, wprawiała w zakłopotanie ewolucjonistów akcentujących adaptacjonizm w ramach doboru naturalnego. Już Darwin ilustrował ten problem, zwracając uwagę na wspomniany już pawi ogon ${ }^{20}$. Takie przykłady można mnożyć.

Chciałbym podkreślić, że ową biegunowość pomiędzy byciem niewidzialnym a koniecznością manifestacji swojej obecności można znaleźć wśród przeważającej większości gatunków zwierząt. Ornamentyka pingwinów, alek, orek, delfinów, rekinów itp. cechuje się tym samym, prostym wzorem kolorów. Spód ciała jest jasny, najczęściej biały, natomiast wierzch jest ciemny, czasami czarny. Zważywszy na to, iż zwierzęta te związane są ze środowiskiem wodnym, taki układ wydaje się „logiczny”. Zwierzę widziane od spodu, a więc na tle jasnego nieba (lub po prostu jaśniejszej, oświetlonej toni), jest mniej widoczne ze względu na jasny spód. Analogicznie - widziane z góry, na ciemnym tle, ze względu na ciemny wierzch jest również trudniej zauważalne ${ }^{21}$. Takie kamuflujące, istotne dla przeżycia wzory i kolory są szczególnie widoczne wśród młodych zwierząt i opiekujących się nimi rodziców (na przykład u samic kaczek). Gdy przyjrzymy się pasiastym wzorom

18 Luty sygnalizuje tylko ten problem; por. J. Luty, Sztuka jako adaptacja, s. 21.

19 G.E. Hill, Bird Coloration, Washington D.C. 2010, s. 189, por. zwł. rozdział Choosing mates. Książka Hilla to kolejny przykład wartościowej refleksji filozoficzno-metodologicznej formułowanej przez przyrodnika. Powyższe uwagi mogą dotyczyć nie tylko ubarwienia ptaków, ale także ich śpiewu — tak samo zachwycającego i ludzi, i ptasie samice; por. Birdsong, Speech, and Language. Exploring the Evolution of Mind and Brain, J.J. Bolhuis and M. Everaert (ed.), London 2013.

20 Por. G.E. Hill, Bird Coloration, s. 171.

21 O tym jak uniwersalny jest to wzór, świadczy ten sam układ kolorów na samolotach z czasów drugiej wojny światowej. 
piskląt perkozów, kaczek, kuraków, ale i warchlaków oraz zwierzyny płowej, to uzmysłowimy sobie, że wspólna ornamentyka u tak różnych grup nie jest przypadkowa, i że chodzi tu o kamuflaż ułatwiający przeżycie.

Jednakże i tu występuja pewne godowe ,manifestacje”. Pingwiny na przykład mają żółte, pomarańczowe lub czerwone akcenty w swoim upierzeniu. Orki zróżnicowanej wielkości płetwy grzbietowe. Sprzyjająca atrakcyjności seksualnej barwna „wstawka” ułatwia jednak atak drapieżnikowi. Jest jak sygnał świetlny naprowadzający atakującego do celu, „dekonspiruje” zwierzę. Proporcje między ornamentyką i innymi cechami wynikającymi z konieczności kamuflażu a cechami związanymi z godową manifestacją bywają subtelne i różnorodne. Ich wyjaśnienie wymagałoby szczegółowego odniesienia się do wszystkich pytań Tinbergena i zilustrowania ich wieloma, bardziej zróżnicowanymi przykładami. Wspólna ornamentyka filogenetycznie odległych od siebie zwierząt wskazuje na przewagę doboru naturalnego „preferującego" mimetyzm i mimikrę. Natomiast zróżnicowanie, kontrast, jaskrawość „kłócące się” z otoczeniem, wskazuje raczej na ową estetyzację narażającą zwierzę na śmierć.

Kiedy zatem mówimy, że ciało zwierzęcia jest „efektem” sprzecznych presji — kamuflażu i godowych manifestacji - to musimy pamiętać także i o tym, że jest ono w konsekwencji jakimś „obrazem”, „odciskiem” środowiska. Konrad Lorenz mówi wręcz o „odwrotnej stronie zwierciadła”. Czy jest tu zatem jakieś miejsce na estetyzację? Sądzę, że tak. Inaczej różne gatunki zajmujące te same nisze byłyby do siebie bardzo podobne; wszystko byłoby uśrednione. To właśnie owa różnorodność gatunków i wewnątrzgatunkowe zróżnicowanie świadczą o estetycznej wrażliwości, o presji nie tylko środowiska, ale i presji „gustów”22.

Podsumowując, warto zadać zasadnicze pytanie. Otóż, czy możemy w ogóle mówić o jakiejś wrażliwości estetycznej, tym samym o zdolności emocjonalnej ptaków (zwierząt)? Tej kwestii obecnie nie rozstrzygnięto, ale, odpowiadając na to pytanie, odwołam się do poglądów dwóch uczonych. Karol Darwin w rozdziale Dobór naturalny sformułował odważną opinię, która i dziś może być traktowana jako nowatorska teza. Pisał mianowicie: „Jeżeli jednak człowiek może wedle własnego poglądu na piękno nadawać w krótkim czasie strojne upierzenie kurom bantamkom, nie widzę podstaw, by wątpić, że samice ptaków, dobierając w ciągu tysięcy pokoleń według swego pojęcia o pięknie najładniej śpiewające lub najpiękniejsze samce, mogły otrzymać widoczne rezultaty" ${ }^{23}$. Co więcej, jeśli uwzględnimy ową biegunowość między potrzebą ukrywania się a manifestowania, to Darwin także i na tę kwestię zwrócił uwagę: „Żywię mocne podejrzenie, że niektóre znane prawa dotyczące upierzenia samców i samic w porównaniu z upierzeniem młodych można wytłumaczyć przy założeniu, że upierzenie jest modyfikowane głównie przez dobór płciowy"24. Warto podkreślić, iż uwagi Darwina można odnieść do wszystkich zwierząt. Natomiast odwołując się w tej kwestii do współczesnych przyrodników,

${ }^{22} \mathrm{Na}$ ten temat więcej zob. Z. Pietrzak, Wiedza jako wielość obrazów. Perspektywa ewolucyjna, [w:] Wiedza, D. Leszczyński (red.), (Studia Systematica 3), Wrocław 2013, s. 221-246; por. także K. Lorenz, Odwrotna strona zwierciadła, tłum. K. Wolicki, Warszawa 1977, zwł. rozdział Życie jako proces poznawczy.

23 C. Darwin, O powstawaniu gatunków, s. 85.

24 Ibidem. 
przywołam opinię Tima Birkheada. W książce Zmysły ptaków autor poświęcił temu zagadnieniu rozdział zatytułowany Uczucia i emocje, w którym na zakończenie pisze: „czytelnik sam musi sobie wyrobić pogląd na to, czy ptaki doświadczają uczuć i emocji. Ja sądzę, że tak, ale — jak skonkludował Thomas Nagel, gdy pytał, co to znaczy być nietoperzem - prawdopodobnie nigdy nie dowiemy się, czy ptaki odczuwają emocje w ten sam sposób co my"25. Birkhead jest bardziej powściągliwy od Darwina, ale jego wyważone ,sądzę, że tak", przemawia wiarygodniej niż zdecydowane „tak", dlatego że owo przekonanie oparte jest na nieustannie wypracowywanej i skutecznej metodologii ${ }^{26}$.

\section{Zakończenie pytanie o sztukę — pytanie o estetyczność przyrody}

Natura ,sama dla siebie ani piękna, ani brzydka, jest chyba tylko ekranem dla ludzkich wewnętrznych piekieł i rajów"27.

Niniejsze rozważania chciałbym zakończyć paroma uwagami, stawiając raczej pytania, niż próbując na nie odpowiedzieć.

Po pierwsze, czy o wrażliwości estetycznej można mówić tylko w odniesieniu do sztuki? Lub inaczej, czy dopiero sztuka, w naszym obecnym rozumieniu, może świadczyć o posiadaniu poczucia piękna wywołującego określone emocje?

Po drugie, jeśli sztuka miałaby być odzwierciedleniem realnie istniejących w przyrodzie własności oraz relacji i budzić przy tym nasze estetyczne doznania, a co więcej, jeśli uznamy, że zwierzęta również tworzą sztukę ${ }^{28}$, to czy natura „sama w sobie” niesie jakieś wartości estetyczne? Czy też są one ściśle podmiotowe (w tym wypadku przez podmiot rozumiem także gatunek)? Chyba wszyscy doznajemy tych samych estetycznych uczuć, a nawet emocji, gdy oglądamy obraz przedstawiający krajobraz górski, jak i wówczas, gdy patrzymy na góry. Estetyczne emocje, które towarzyszą naszemu stosunkowi do sztuki, towarzyszą także naszemu stosunkowi do przyrody, ale czy to oznacza, że przyroda „sama w sobie" jest piękna? Czy też ów (piękny?) krajobraz staje się pejzażem wykreowanym przez nasz umysł?

Po trzecie, jeśli uznamy, że zwierzęta tworzą sztukę i że one same są dziełami sztuki, to musimy pamiętać, iż świat widziany ich oczyma i porządkowany przez ich umysły jest odmienny od naszego. Jednak, jeżeli ludzie i zwierzęta (na przykład samice ptaków) uznają za piękne tę samą ornamentykę i kolorystykę, to możemy mówić o jakiejś wspólnocie odczuć estetycznych. A jeżeli tak, to w jakim

25 T. Birkhead, Zmysły ptaków, tłum. W. Stanisławski, Łódź 2012, s. 180.

${ }^{26}$ Kwestie metod stosowanych w opisywanych przez Birkheada badaniach, są jednym z zasadniczych wątków tej książki.

27 C. Miłosz, Widzenia nad Zatoka San Francisco, Kraków 1989, s. 12. Miłosz poświęca wiele miejsca w swojej twórczości relacjom człowieka z przyroda, jego potrzebom estetyzowania natury, ale także i mitologizowania jej; por. także Dolina Issy.

28 J. Luty, Sztuka jako adaptacja, s. 162 n. 
stopniu owa wspólnota potwierdza ideę istnienia jakiegoś obiektywnego piękna? Czy tak rozumiana sztuka sugerowałaby, że przyroda ma jakąś obiektywną wartość estetyczną, wartość ,samą w sobie”?

Aby podziwiać przyrodę, człowiek musi „ulokować” się na zewnątrz niej, musi się wyalienować, musi stać się koneserem. Człowiek nieustannie głodny ${ }^{29}$, walczący o przetrwanie traktuje ją jako zasób pożywienia i źródło zagrożeń. A zatem czy malowidła naskalne są świadectwem estetycznego podziwu dla otaczającej natury, czy sposobem na „zaklinanie” przyrody, manipulowanie nią i opisem „czynów heroicznych"?

Sformułowane tu pytania, odnoszące się do estetyczności przyrody, można powiązać z kwestiami etycznymi, ekologicznymi, polityczno-gospodarczymi, a nawet teologicznymi. Pytanie o wartość przyrody zawiera wszystkie owe konteksty i stawia nas przed dylematem - czy uznajemy, że przyroda jest wartością samą w sobie, czy też przedstawia wartość tylko ze względu na nas samych, na nasze potrzeby?

Sądzę, iż słowa z eseju Czesława Miłosza najtrafniej wyrażają intencje przyświecające powyższym refleksjom. Osobiście mógłbym tylko dopytać, czy inne gatunki, wykazujace zdolności do tworzenia sztuki, estetyzujące przyrodę, traktują ją jako egzemplifikacje swoich „piekieł i rajów”? Czy w ogóle mają swoje „piekła i raje”?

Akceptacja idei, że sztuka jest efektem procesów biologicznych i że można wyjaśnić jej genezę oraz mechanizmy w kategoriach historii ewolucyjnej, powoduje, iż dysjunkcja: natura i kultura (sztuka) z tej perspektywy jest sztuczna, ponieważ wszystko jest naturą ${ }^{30}$. Teoria ewolucji zaciera granice między tym, co materialne i biologiczne, a tym, co psychiczne i umysłowe, a więc kulturowe. Jednak — jak sądzę - skoro wymusza ona poznawczą i metodologiczną różnorodność wyrażającą się w pytaniach Tinbergena, to także wskazuje na odrębność i nieredukowalność do najbardziej fundamentalnych (czyli kwantowych) procesów fizycznych zjawisk biologicznych oraz wynikajacych z nich zjawisk umysłowych ${ }^{31}$.

${ }^{29}$ O wpływie głodu na zachowanie ludzi i możliwości pojawienia się wyższych potrzeb w tym także estetycznych por. M. Konarzewski, Na początku był głód, Warszawa 2005.

30 Chciałbym przy tym zaznaczyć, że nie jestem zwolennikiem ontologicznego redukcjonizmu sfery umysłowej do sfery procesów fizycznych. Uznając związek przyczynowo-skutkowy między tymi sferami rzeczywistości, skłaniam się ku idei emergencji, którą zaproponował J.R. Searle; por. J.R. Searle, Umyst. Krótkie wprowadzenie, tłum. J. Karłowski, Poznań 2010.

31 Por. J. Al-Khalili, J. McFadden, Życie na krawędzi. Era kwantowej biologii, tłum. T. Krzysztoń, Warszawa 2018.

Studia Philosophica Wratislaviensia vol. XVI, fasc. 1, 2021

(C) for this edition by CNS 


\section{Bibliografia}

Al-Khalili J., McFadden J., Życie na krawędzi. Era kwantowej biologii, tłum. T. Krzysztoń, Warszawa 2018.

Birdsong, Speech, and Language. Exploring the Evolution of Mind and Brain, J.J. Bolhuis, M. Everaert (ed.), London 2013.

Birkhead T., Zmysły ptaków, tłum. W. Stanisławski, Łódź 2012.

Darwin Ch., O powstawaniu gatunków, tłum. S. Dickstein, J. Nusbaum (oprac. J. Popiołek, M. Yamazaki), Warszawa 2013.

Dawkins R., Fenotyp rozszerzony. Dalekosiężny gen, tłum. J. Gliwicz, Warszawa 2003.

Hanson T., Pióra. Ewolucja cudu natury, tłum. A. Wawrzyński, Łódź 2019.

Hill G.E., Bird Coloration, Washington D.C. 2010.

Konarzewski M., Na początku był głód, Warszawa 2005.

Krebs J.R., Davies N.B., Wprowadzenie do ekologii behawioralnej, tłum. M. Golachowski, Warszawa 2014.

Lorenz K., Odwrotna strona zwierciadła, tłum. K. Wolicki, Warszawa 1977.

Luty J., Sztuka jako adaptacja. Uniwersalizm w estetyce ewolucyjnej, Kraków 2018.

Mayr E., To jest biologia. Nauka o świecie ożywionym, tłum. J. Szacki, Warszawa 2002.

Miłosz C., Widzenia nad Zatoka San Francisco, Kraków 1989.

Pietrzak Z., Wiedza jako wielość obrazów. Perspektywa ewolucyjna, [w:] Wiedza, D. Leszczyński (red.), (Studia Systematica 3), Wrocław 2013, s. 221-246.

Prum R.O., Ewolucja piękna. Jak Darwinowska teoria wyboru partnera kształtuje świat zwierzat $i$ nas samych, tłum. K. Skonieczny, Kraków 2019.

Searle J.R., Umyst. Krótkie wprowadzenie, tłum. J. Karłowski, Poznań 2010.

Tinbergen N., On aims and methods of ethology, „Zeitshrift für Tierpsychologie” 20, (1963), s. 410-433.

Waal F. de, Bystre zwierzę. Czy jesteśmy dość madrzy, aby zrozumieć mądrość zwierząt, tłum. Ł. Lamża, Kraków 2016. 